\begin{tabular}{l|l|l|l|l}
\hline Volume 2 & Issue 1 & April (2021) & DOI: 10.47540/ijsei.v2i1.187 & Page: $39-47$ \\
\hline
\end{tabular}

\title{
Dispersal of Insects at Honitetu Forest in West Seram District
}

\author{
Fransina Latumahina ${ }^{1}$, Cornelia Wattimena ${ }^{2}$, Gabriella Mattinahoru ${ }^{3}$ \\ ${ }^{1,2,3}$ Department of Forestry, Faculty of Agriculture, Universitas Pattimura, Ambon, Indonesia
}

Corresponding Author: Fransina Latumahina; Email: fransina.latumahina@yahoo.com

\begin{tabular}{|c|c|}
\hline A R T I C L E I N F O & A B S T R A C T \\
\hline $\begin{array}{l}\text { Keywords: Abundance; Dispersal; } \\
\text { Diversity; Forest Education; Insects. }\end{array}$ & $\begin{array}{l}\text { The research objective was to determine the spread of insect species in educational } \\
\text { forests and the diversity and abundance of insects. The research was carried out in } \\
\text { the Educational Forest of Honitetu in May - June } 2020 \text { using the method of drawing }\end{array}$ \\
\hline : 12 March 2021 & sample plots in 3 hectares, then an observation path was made using the path \\
\hline :09 April 2021 & method for insect inventory and systematic sampling for vegetation inventory with \\
\hline : 14 April 2021 & $\begin{array}{l}\text { the plot size. } 20 \mathrm{~m} \text { wide, } 100 \mathrm{~m} \text { long with a distance between lines of } 20 \mathrm{~m} \text {. Insects } \\
\text { were collected using hand-collecting and pitfall trap methods at a distance of } 10 \mathrm{~m} \\
\text { and bait traps every } 10 \mathrm{~m} \text {. The results of the study found } 6462 \text { insects consisting of } \\
62 \text { species in } 12 \text { orders, are Coleoptera, Hymenoptera, Orthoptera, Diptera, } \\
\text { Blattaria, Hemiptera, Lepidoptera, Phasmatodea, Opiliones, Araneae, Mantodea in } \\
35 \text { families, namely Chrysomelidae, Cerambycidae, Formicidae, Apidae, } \\
\text { Calliphoridae, Tettigoniidae, Acrididae, Grylludae, Blaberidae, Pentatomidae, } \\
\text { Piesmatidae, Culicidae, Carabidae, Alydidae, Nanomatidae, Eresidae, Vespidae, } \\
\text { Asilidae, Zodaridae, Buprestidae, Phasmatidaal, Blattidae, Platypezidae, } \\
\text { Sarcophidae, Noctuidae, Rhaphidophoridae, Sclerosomatidae, and Ichneumonidae. } \\
\text { Most species found from the Order Hymenoptera Family Formicidae and the most } \\
\text { diminutive species found are the Order Lepidoptera Family Danaidae, Papilionidae, } \\
\text { Nymphalidae, Order Hymenoptera Family Braconidae, and Order Opiliones Family } \\
\text { Sclerosomatidae. The maximum H 'value is } 4.127 \text {, the evenness index of } 0.628 \text { is } \\
\text { classified as moderate, and the dominance index is } 0.111 \text { and is classified as low. }\end{array}$ \\
\hline
\end{tabular}

\section{INTRODUCTION}

In Indonesia, biodiversity includes various levels, from gene diversity, species diversity, and ecosystem diversity. One of Indonesia's prominent species diversity is the diversity of insects compared to other countries (Murdoch et al., 1972). The number of insects in Indonesia is approximately 250,000 species, or about $14 \%$ of all biota in Indonesia (Sanchez-Bayo \& Wyckhuys, 2019). Insects or insects are animals with the most significant number of species, namely as much as $3 / 4$ percent of all animal species on earth (Godfray et al., 1999) (Matos-Maraví et al., 2018). Insects are Arthropods whose bodies are divided into the head, chest, and abdomen, the head has one pair of antennae, and the chest with three pairs of legs usually has one or two pairs of wings on the adult level (Triplehorn et al., 2005). Insects are one animal that can survive in diverse/varied habitats, have a high reproductive capacity, the ability to eat different types of food, and the ability to save themselves from their enemies (Hughes et al., 2000). Indonesia is known as one of those countries with a very high diversity of flora and fauna (mega biodiversity). Indonesia is located in a tropical region with a stable climate, and geographically it is an archipelagic country located between two continents, namely Asia and Australia (Primack et al., 1998). One of the biodiversity that can be Indonesia is proud to be insects, by number 250,000 species or about $15 \%$ of the total species of biota major known in Indonesia (Bappenas, 1993). One of the biodiversity that Indonesia can be proud of is insects, with 250,000 species or about $15 \%$ of the number of main biota species known in Indonesia (Bappenas, 1993). Indonesia is estimated to have about $10 \%$ of beetle species of all beetles in the world (Noerdjito, 2003). Most insects walk, but some insects fly and jump.

Insects have several essential values, including ecological values, endemism, conservation, education, culture, aesthetics, and economics (Janz 
et al., 2006). However, insects' spread is limited by suitable geological and ecological factors, resulting in differences in the diversity of insect species diversity in climate, season, altitude, and food type. The diversity of insects, in general, will also be determined by environmental factors (Nietschke et al., 2007). Each type of insect has its suitability to a particular environment, or the presence of a type of insect in a habitat is influenced by environmental factors including the ability of insects to spread, habitat selection, air temperature conditions, humidity, soil moisture, light, rainfall, vegetation, and availability of food (Godfray et al., 1999). Maluku Province is rich in fantastic biodiversity; a high level of species endemicity characterizes this diversity. The uniqueness and high biodiversity of Maluku are widespread in all regions, with different concentrations of species abundance on each island. Forest is a unitary ecosystem in the form of a stretch of land containing biological natural resources dominated by trees in a natural environment, which cannot be separated from one another.

Thus the forest has an important function and role for the surrounding environment. Forests are also a collection of trees that grow densely and densely; plants in the forest are not only in the form of trees but also in moss, shrubs, weeds, and other plants. Apart from plants, in the forest, there are various kinds of wild animals, insects, wild animals, and other types of animals, so it is said that forests have very high and beneficial biodiversity. Research carried out in the Batu Gajah river basin, Ambon City, found 2398 individual insects consisting of 8 order, 32 families, and 91 individual. Educational Forest is one of the forest areas in Honitetu State, West Seram Regency, which has an unknown and unidentified insect diversity. Hence, the study of insect diversity is an exciting object to research because insect diversity will be an indicator of the forest area's stability. The research objective was to determine the spread of insect species in educational forests and insects' diversity and abundance. Honitetu educational forest is one of the forest areas that also acts as a protected area to protect water sources and prevent landslides and floods around the Honitetu village area.

\section{MATERIALS AND METHOdS}

The research was carried out in the Honitetu State Education Forest, West Seram Regency. Honitetu is located in the mountainous region of the island of Seram, and the main village of the five countries in Inamosol District, which is located in a mountainous area with an altitude of $\pm 500 \mathrm{~m}$ above sea level and has an administrative area of $268 \mathrm{Km}$. Honitetu is located at 2 "55'LS-3" 25'LS and 128 "15'BT-128" 45'BT with the boundaries as follows north, it is bordered by Huku Anakota and Rambatu. In the south, it is bordered by Watui and Huku Kecil To the east is bordered by Huku Kecil To the west is bordered by Rumberu. The research was carried out in September 2019 until it was finished using several types of equipment, namely Pitfall traps, light traps, Sweep nets, Bait traps, microscopes. Tweezers, thermohygometer, GPS, phiband, hagameter, altimeter, glass bottles, papilot paper, tape measure, string, label paper, writing instruments, digital cameras, and the critical book of insect determination (Wijaya et al., 2015).

While the materials used are $70 \%$ alcohol, water, detergent, sugar solution, and canned fish. Research procedure The research was carried out using sampling methods in an area of 3 hectares with a systematic inventory sampling method with a length of $100 \mathrm{~m}$, a width of $20 \mathrm{~m}$, and a distance between paths of $20 \mathrm{~m}$. Insects were collected using five insect-taking techniques, which are Hand collecting. The hand collecting method is direct sampling. Each type of insect was collected using hands or tweezers and put into a collection bottle containing $70 \%$ alcohol. Observations of all types of insects live around low vegetation, between rocks, soil surface, mounds, and wood chips Light Trap. These traps are used to catch insects that respond to light at night (nocturnal). The traps were set at 6.00-7.00 pm using a petromax lamp as a light source. Petromax lamps are hung at the height of $2.5 \mathrm{~m}$ from the ground. Pittfaal Trap. Used to catch insects that live above the ground, which are installed on each observation path using a plastic cup with a diameter of $\pm 15 \mathrm{~cm}$, where the surface of the glass is planted parallel to the ground with a distance of $10 \mathrm{~m}$ per pitfall trap $\mathrm{m}$ filled with soap solution as much as $\pm 400 \mathrm{ml}$ and left for 24 hours. Sweep net. The trap is made of a light and strong material such as gauze, easy to swing and visible insects can be seen. Catching insects with nets is 
carried out on each line of observation made. The insects that were caught were put in a glass bottle. Bait Trap uses sugar solution and canned fish placed on a plastic plate. The plate containing the bait will be tied to the tree at a distance of $10 \mathrm{~m}$ on each observation path made and left until $5.00 \mathrm{pm}$. The insects found in the field are grouped according to their order and method of collection. Insects that are recognized as species are identified directly in the field, while insects that are not yet known are identified by observing their outer shape (morphology) with the aid of a microscope at the Silviculture Laboratory of the Forestry Department, Faculty of Agriculture, Pattimura University by referring to the critical book of insect determination to the species level. The identified insects were collected by the wet method and dry method.

The data analysis was carried out in a descriptive quantitative manner, with the experimental method, namely direct observation or sampling from the observation location. Insect data processing uses the Shannon Winner Diversity Index $\left(\mathrm{H}^{\prime}\right)$, Abundance Index $(\mathrm{K})$ and Dominance Index (C), and Evenness Index (H. T. Odum \& Odum, 2003). Diversity Index (H) Diversity index is used to compare the high and low species diversity of insects using the Shannon-Weiner index $\left(\mathrm{H}^{\prime}\right)$ with the following formula:

$\mathrm{H}^{\prime}=-\sum_{\mathrm{i}=1}^{\mathrm{n}} \frac{\mathrm{ni}}{\mathrm{N}} \log \frac{\mathrm{ni}}{\mathrm{N}}$

Evenness Index (E) Evenness of insect species using the Evenness Index (E) from (H. T. Odum \& Odum, 1955) is :

$\mathrm{E}=\frac{\mathrm{H}^{\prime}}{\operatorname{Ln}(\mathrm{S})}$

Dominance Index (D) Determination of the dominant insect species in the educational forest using Simpson's Dominance Index (E. P. Odum, 1969).

$\mathrm{C}=\sum(\mathrm{ni} / \mathrm{N})^{2}$

\section{RESULTS AND DISCUSSION Spread of Insects}

The study results found 6,462 insects consisting of 62 species divided into 12 orders and 35 families, namely Coleoptera, Hymenoptera, Orthoptera, Diptera, Blattaria, Hemiptera, Lepidoptera, Phasmatodea, Opiliones, Araneae, and Mantodea. Some families of an insect in the forest are Chrysomelidae, Cerambycidae, Formicidae, Apidae, Calliphoridae, Tettigoniidae, Acrididae, Grylludae, Blaberidae, Pentatomidae, Piesmatidae, Culicidae, Carabidae, Alydidae, Nanomatidae, Eresuphids, Vespidae, Assrestzidae, Zodaridae, Sarcophagidae, Mantidae, Araneidae, Nymphalidae, Papilionidae, Danaidae, Noctuidae, Rhaphidophoridae, Sclerosomatidae, and Ichneumonidae.

The species found chiefly came from the Hymenoptera order. The Formicidae family and the most diminutive species were the Lepidoptera Order, the Danaidae family, Papilionidae, Nymphalidae, the Hymenoptera order, the Braconidae family and the Order Opiliones, the Sclerosomatidae family. The results found that the Formicidae family was mainly found at the research location because the life of the Formicidae family was very much influenced by the availability of food sources, namely shrubs, shelter, and nesting, which were available in large quantities above the ground and the soil.

According to (Asfiya et al., 2015). This family is an insect species found in every habitat and is dominant on the ground. This family is known to have various species and includes social insects and cosmopolitan. (Ipser et al., 2004). They are easily found in large numbers. There are 13 species dominant from Hymenoptera specially Formicidae family at the research location, scattered in each observation pathdescribe the order that is most commonly found and least found and the factors that caused it. (a)

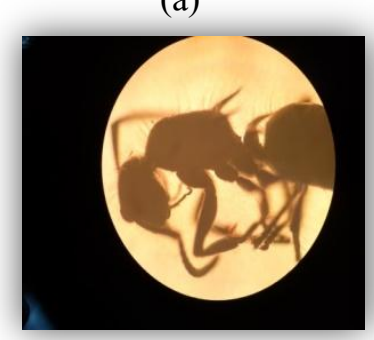

(b)

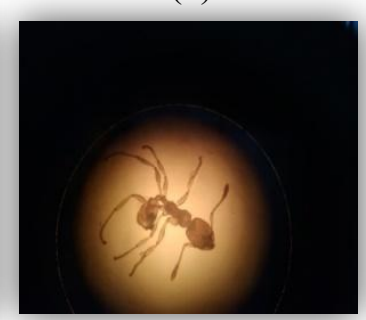

41 (c)

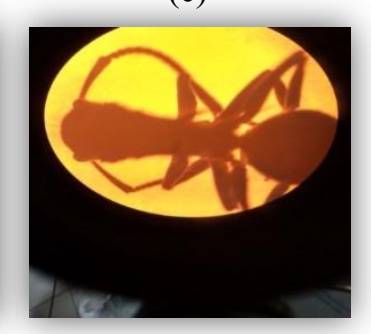


(d)

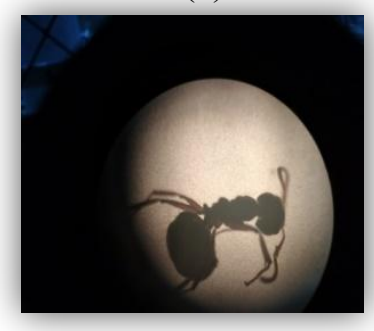

(h)

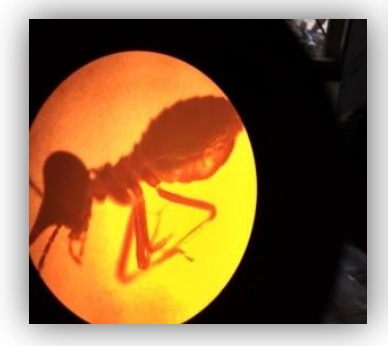

(j)

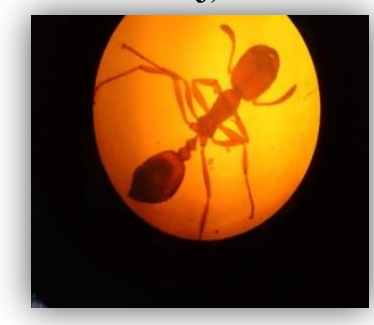

(e)

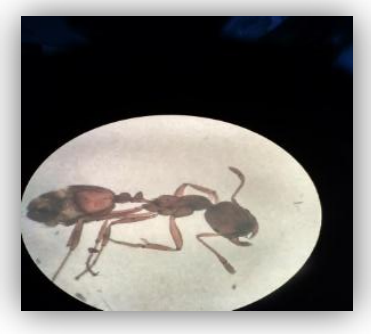

(i)

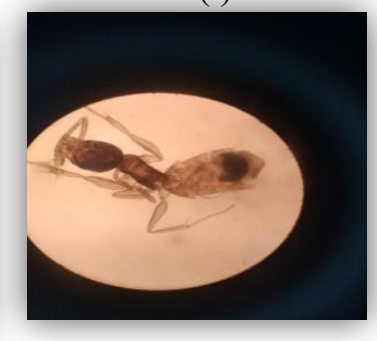

$(\mathrm{k})$

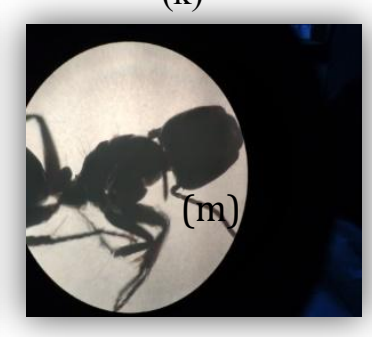

(m)

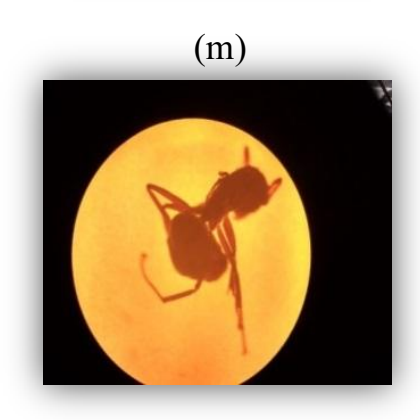

(f)

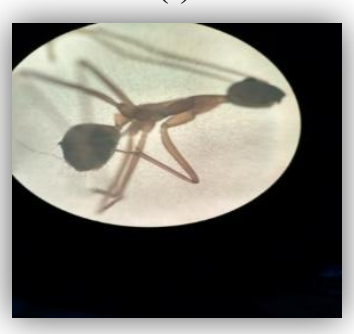

(j)

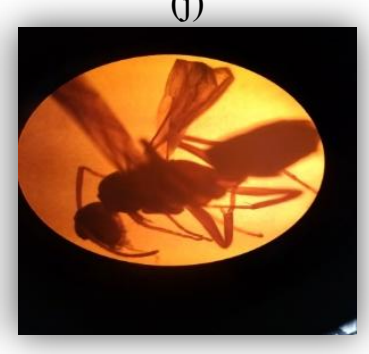

(1)

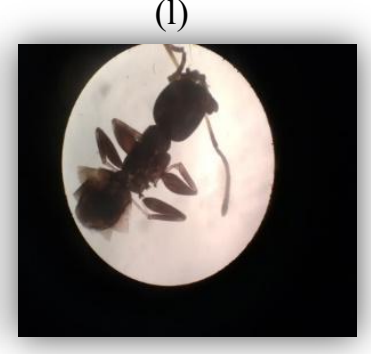

Figure 1. (a) Species of the Order Hymenoptera from the Formicidae family found at the research location

(a) Delichoderusthoracicus, (b) Anoplolepisgracilipes, (c) Formica exsectoides, (d)

Camponotusnovaeboracensis, (e) Oechophyllasmaragdina, (f) Paratrechinalongicornis, (g)

PlectrocteanaSp, (h) SolenopsisSp, (i) Lasiusfuliginosus, (j) Monomoriumcyaneum, (k)

Odontoponeratransversa, (1) Nylanderiavividula, (m) Myrnicasabuleti.

Hymenoptera insects' distribution at the research location is in different places, namely under the leaf blade, in rolled plant leaves, above the ground, in the ground, creeping on tree trunks, between fallen plant branches, and on the bait that is installed (Latumahina, 2019). Hymenoptera has two pairs of wings, with the front wings more significant than the hind wings, the type of mouth to bite, and some to bite and lick. The holometabolous metamorphosis of the last segment of his abdomen turned into a pricking device. Insects from the Formicidae family are thought to have a significant role because Formicidae can indicate ecosystem stability. After all, the higher the diversity of the Formicidae, the food chain and predation processes, parasitism, competition, symbiosis, and predation in the ecosystem are increasingly complex and varied to create balance and stability (Philpottlandlnge\& 
Recht, 2006). Ants are a group of animals based on their biology and ecology play an important role as a predator, decomposer, and herbivore in the ecosystem (Holldobler and Wilson, 1990). At the time of the research, it was found that the Order of Lepidoptera was found very little at the research location because the presence of butterflies in an area depends on a suitable host plant which is a source of food and protection for its survival. This

(a)

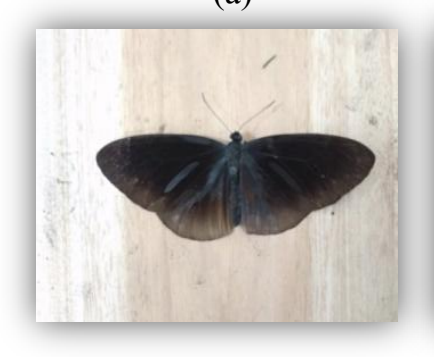

(d)

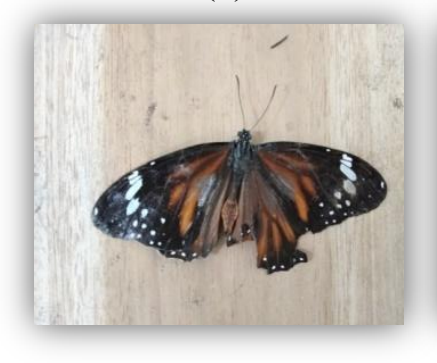

statement is supported by (Dunn et al., 2007) which states that forage plants' availability influences the abundance of butterfly species in a habitat. There are six species from the order of Lepidoptera found at the research location in two families, namely the Nymphalidae and Papilionidae families. Some species found in location are Euploeamodesta, Euploeacarmeri, Coenonymphaoedippus, Hypolimnasmisipus, Papiliomemnonand Papiliodeiphobus (b)

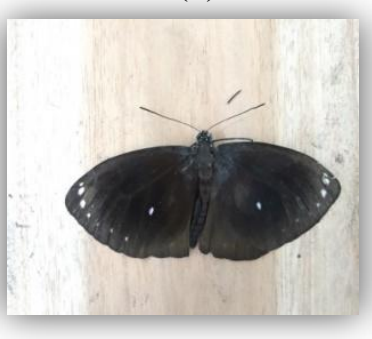

(e)

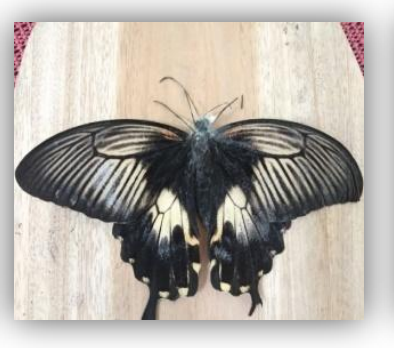

(c)

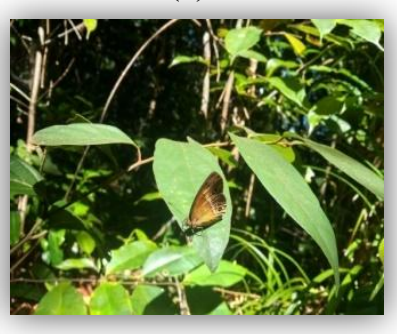

(f)

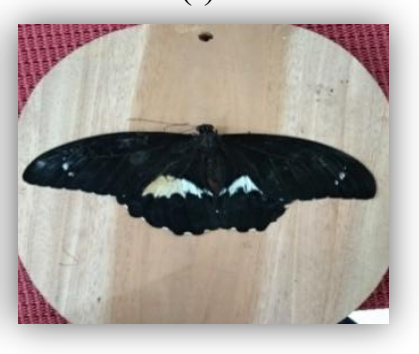

Figure 2. Species of the Order Lepidoptera found at the research location (a) Euploeamodesta, (b) Euploeacarmeri, (c) Coenonymphaoedippus, (d) Hypolimnasmisipus, (e) Papiliomemnon, (f) Papiliodeiphobus).

At the time of research, the humidity ranged temperature of $150{ }^{\circ} \mathrm{C}$, and a maximum temperature from 150C-260C, a good condition and suitable for of $450^{\circ} \mathrm{C}$. Populations of this species can be insect life. This statement is supported by (Muñoz- geographically isolated due to unsuitable soil or Pedreros et al., 2018) who states that the optimum water. There are three species of this order found at air temperature can support insect life, the optimum air temperature for insects is $250^{\circ} \mathrm{C}$ has a minimum

(a)

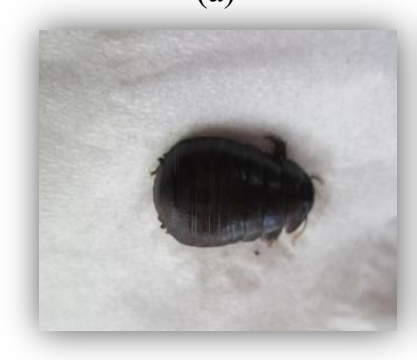

(b)

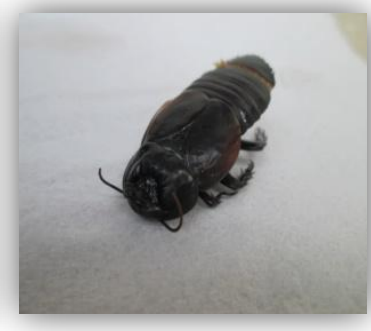

(c)

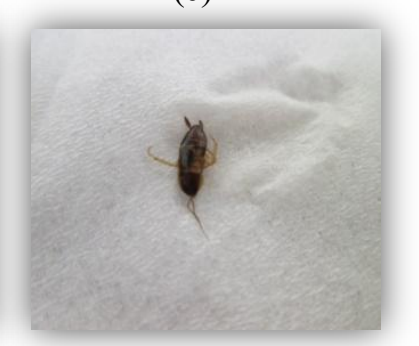

Figure 3. Species of the Order Coleopterafound at the research location (a) Macropanesthia rhinoceros,

(b) Panesthiacribrata, (c) Parcelioscaber.

Insects from the Order Araneae are found on animal with two body segments, four legs, the leaves' underside, hanging with the help of wingless, and no chewing mouth. There are three threads $30 \mathrm{~cm}$ long. This order is a kind of book species of this order found in the research location, 
spread in 3 families, namely Araneidae, Eresidae and Zodaridae.

(a)

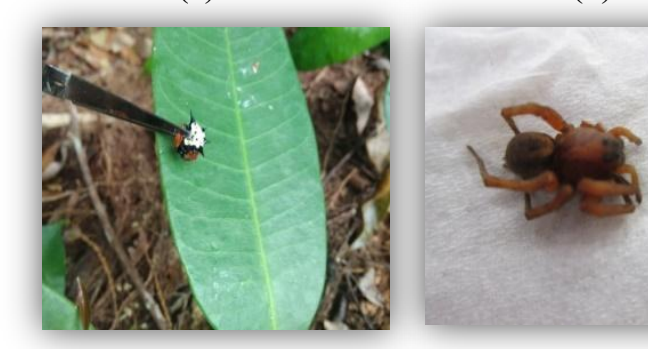

(c)

(b)

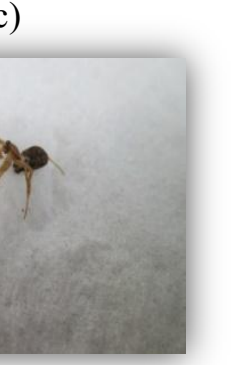

Figure 4. Species of the Order Hymenoptera found at the research location

(a) Gasteracanthacancriformis, (b) Eresussandaliatus, (c) Zodariionrubidun.

This order's species are quite often found at night, flying near and perching on the lights installed on each observation path. It is suspected that these insects need a little light to guide them in their activities. Night insects are very interested in bright light because they think that the color of the lamp matches the color of the food (Wenny et al., 2011). According to (Subekti et al., 2008) insect's body size is small to medium, has an antenna like a thread, and the body of this insect is sturdy and hairy. The species obtained at the research location at night were Mythimnavitelline, and Mythimnaconvects (Kubu et al., 2016). Species diversity, evenness, and dominance of insects at the research location The results of the calculation of the index of species diversity, evenness and dominance of insect species in the Educational Forest Area in Honitetu State can be seen in Table 2 below.

Table 2. Species diversity index, evenness, and species dominance.

\begin{tabular}{|c|c|c|}
\hline \multicolumn{3}{|c|}{ Species diversity index, evenness, and species dominance. } \\
\hline $\begin{array}{c}\text { Diversity Index } \\
\left(\mathrm{H}^{\prime}\right)\end{array}$ & Evenness Index (E) & $\begin{array}{c}\text { Dominance Index } \\
\text { (D) }\end{array}$ \\
\hline $\mathbf{2 . 5 9 2}$ & $\mathbf{0 . 6 2 8}$ & $\mathbf{0 . 1 1 1}$ \\
\hline
\end{tabular}

The insect diversity index in the forest is 2.592 and it is classified as moderate, where the diversity index value is an indicator of the abundance or number of insects in the protected forest. The evenness index of 0.628 is classified as low, and the dominance index of 0.111 is also classified as low. The value of the insect diversity index in the forest is influenced by environmental and physical factors, namely human activities around the forest, microclimate conditions that are too extreme for insects and food that insects do not like. This statement is supported by Haneda (2013) that quality factors influence insect diversity. And the quantity of food. Insects operate in optimal environmental conditions, while less than optimal conditions in nature cause low insect activity. The value of insect diversity is thought to be influenced by the various vegetation diversity levels in the forest, which is a source of food, a place to live and breed for insects.
More diverse the habitat structure, the diversity of plant species and the varied vegetation structures, the greater the diversity of insects that occupy a location. Insects from the Formicidae family influence the level of insect diversity in the forest (Meranti et al., 2014). A number of families and populations strongly influences a diversity index level (Herdiana, 2010). A number of species are more significant in one family, the diversity is moderate compared to the number of small species but includes several families. The evenness index value in the forest was 0.628 ; this indicates that the insect species found were not evenly distributed in the forest, where insects from the Formicidae family had many species and dominated other families. According to (Nct, 2017) the evenness value will tend to be high if the population in one family does not dominate the population of other families; on the contrary, evenness tends to be low if one family has a population that dominates the number of other populations (Hasriyanty et al., 2015). 
The level of individual abundance between species in the community is still low. The value of the dominance index for insect species is 0.111 and is low; this indicates that none of the abundances of individual species found dominates so that the dominance index is low. This condition shows that the habitat of the forest habitat has a very varied availability of food, host plants, shelter, and breeding for insects to impact the lives of insects in the forest. The presence of insects from the Formicidae family in the area has become an indicator of the stability of the ecosystem because the higher the diversity of the Formicidae, the food chain and the process of predation, parasitism, competition, symbiosis, and predation in the ecosystem are increasingly complex and varied so that it creates balance and stability.

\section{ConClusion}

The insect species found in the Honitetuforest are 62 species, with a total of 6,462 individuals in 12 orders, namely Coleoptera, Hymenoptera, Orthoptera, Diptera, Dictyoptera, Hemiptera, Lepidoptera, Blattaria, Phasmatodea, Opiliones, Araneae, Mantodea which are scattered in 35 families, namely Chrysomelidae, Cerambycidae, Formicidae, Apidae, Calliphoridae, Tettigoniidae, Acrididae, Grylludae, Blaberidae, Pentatomidae, Piesmatidae, Culicidae, Carabidae, Alydidae, Nanomatidae, Eresididae, Vespionidae, Assilzidae, Zodaridae, Mantidae, Coccinellidae, Araneidae, Nymphalidae, Papilionidae, Danaidae, Noctuidae, Rhaphidophoridae, Sclerosomatidae, and Ichneumonidae with the most common species found, namely from the Order of Hymenoptera. The value of the insect diversity index $\left(\mathrm{H}^{\prime}\right)$ is 2.592; this value indicates that the diversity value of insects is in the medium category, the evenness index value (E) 0.628 the evenness value of insects is relatively even and shows that the abundance of insects found in the research location is spread out. Fairly evenly distributed throughout the entire line of observation, and the species dominance index value (D) 0.111 , this value shows that the dominance value of insect species is in a low category and indicates that the abundance of individual species is not dominant.

The presence of insects in the area has become an indicator of the stability of the ecosystem because the higher the diversity of the insect, the food chain and the process of predation, parasitism, competition, symbiosis, and predation in the ecosystem are increasingly complex and varied so that it creates balance and stability. The diversity of insects in the educational forest is thought to be influenced by the quality and quantity of food in the forest. Optimal environmental conditions also support the level of insect diversity. However, less than optimal conditions in nature lead to low insect activity where the more diverse habitat structures (diversity of plant species and vegetation structures), the greater the diversity of insects that occupy a location.

\section{REFERENCES}

Asfiya, W., Lach, L., Majer, J. D., Heterick, B., \& Didham, R. K. (2015). Intensive agroforestry practices negatively affect ant (Hymenoptera: Formicidae) diversity and composition in Southeast Sulawesi, Indonesia. Asian Myrmecology, 7(1), 87-104.

Dunn, R., Sanders, N., \& Fitzpatrick, M. (2007). Global ant (Hymenoptera: Formicidae) biodiversity and biogeography-a new database and its possibilities. Myrmecological News, September, 77-83.

Godfray, H. C. J., Lewis, O. T., \& Memmott, J. (1999). Studying insect diversity in the tropics. Philosophical Transactions of the Royal Society B: Biological Sciences. https://doi.org/10.1098/rstb.1999.0523

Hasriyanty, H., Rizali, A., \& Buchori, D. (2015). Keanekaragaman semut dan pola keberadaannya pada daerah urban di Palu, Sulawesi Tengah. Jurnal Entomologi Indonesia. https://doi.org/10.5994/jei.12.1.39

Herdiana, N. (2010). Potensi Serangan Hama Tanaman Jati Rakyat Dan Upaya Pengendaliannya di Rumpin, BOGOR. Jurnal Penelitian Hutan Tanaman. https://doi.org/10.20886/jpht.2010.7.4.201209

Hughes, J. B., Daily, G. C., \& Ehrlich, P. R. (2000). Conservation of insect diversity: A habitat approach. Conservation Biology. https://doi.org/10.1046/j.15231739.2000.99187.x

Ipser, R. M., Brinkman, M. A., Gardner, W. A., \& Peeler, H. B. (2004). A Survey of GroundDwelling Ants (Hymenoptera: Formicidae) 
in Georgia. Florida Entomologist, 87(3), 253-260. https://doi.org/10.1653/00154040(2004)087[0253:asogah]2.0.co;2

Janz, N., Nylin, S., \& Wahlberg, N. (2006). Diversity begets diversity: Host expansions and the diversification of plant-feeding insects. BMC Evolutionary Biology. https://doi.org/10.1186/1471-2148-6-4

Kubu, G., Sawang, K., Aceh, K., Kelompok, R. A., Investment, R., \& Bireuen, K. (2016). Terhadap Pengendalian Hama Ulat Pada Bibit Kakao (Theobroma cacao L) Saifuddin Mahasiswa Agroteknologi Fakultas Pertanian Universitas Almuslim. 3(3).

Latumahina, F. (2019). Respon Semut Terhadap Kerusakan Antropogenik Pada Hutan Lindung Sirimau, Ambon. Agrologia, 5(2), 53-66. https://doi.org/10.30598/a.v5i2.188

Latumahina, F., \& Mardiatmoko, G. (2019). The Effect of Climate Change on Abundance and Diversity of Ant in Tuhaha Forest at Mollucas Province on Indonesia. International Journal of Current Microbiology and Applied Sciences, 8(05), 2397-2408.

M.A Wattimena, C., Latumahina, F., \& Khomsah Kartikawati, N. (2020). Inventarisasi serangga dan tingkat kerusakan yang ditimbulkan pada tegakan jati (Tectona grandis LINN. F) di areal hutan tanaman rakyat (HTR) negeri Hila Kabupaten Maluku Tengah. Jurnal Pemuliaan Tanaman Hutan. https://doi.org/10.20886/jpth.2020.14.1.1-8

Matos-Maraví, P., Clouse, R. M., Sarnat, E. M., Economo, E. P., LaPolla, J. S., Borovanska, M., Rabeling, C., Czekanski-Moir, J., Latumahina, F., Wilson, E. O., \& Janda, M. (2018). An ant genus-group (Prenolepis) illuminates the biogeography and drivers of insect diversification in the Indo-Pacific. Molecular Phylogenetics and Evolution, 123(November 2017), 16-25.

Meranti, T., Shorea, M., Di, L., Pt, P., Hutani, G., Kec, L., \& Leisela, F. (2014). Studi tingkat kerusakan akibat hama daun pada tanaman meranti merah ( shorea leprosula) di areal persemaian pt. gema hutani lestari kec. fene leisela. 36-45.

Muñoz-Pedreros, A., González-Urrutia, M., EncinaMontoya, F., \& Norambuena, H. V. (2018).
Effects of vegetation strata and human disturbance on bird diversity in green areas in a city in southern Chile. Avian Research, 9(1), 1-15.

Murdoch, W. W., Evans, F. C., \& Peterson, C. H. (1972). Diversity and Pattern in Plants and Insects. Ecology.

https://doi.org/10.2307/1934297

Nct. (2017). Effectiveness of Screening and Brief Interventions for Alcohol and Tobacco During Breast Cancer Treatment (ONKODETOX).

Https://Clinicaltrials.Gov/Show/Nct0337173 2.

Nietschke, B. S., Magarey, R. D., Borchert, D. M., Calvin, D. D., \& Jones, E. (2007). A developmental database to support insect phenology models. Crop Protection, 26(9), 1444-1448.

Odum, E. P. (1969). The strategy of ecosystem development. Science. https://doi.org/10.1126/science.164.3877.262

Odum, H. T., \& Odum, B. (2003). Concepts and methods of ecological engineering. Ecological Engineering. https://doi.org/10.1016/j.ecoleng.2003.08.00 8

Odum, H. T., \& Odum, E. P. (1955). Trophic Structure and Productivity of a Windward Coral Reef Community on Eniwetok Atoll. Ecological Monographs. https://doi.org/10.2307/1943285

Philpottlandlnge, S. M., \& Recht, A. (2006). Biodiversity in tropical agroforests and the ecological role of ants and ant diversity in predatory function. Ecological Entomology, 31, 369-377.

Sanchez-Bayo, F., \& Wyckhuys, K. A. G. (2019). Response to "Global insect decline: Comments on Sánchez-Bayo and Wyckhuys (2019)." In Biological Conservation. https://doi.org/10.1016/j.biocon.2019.03.020

Schowalter, T. (2006). Insect Ecology. In Insect Ecology. https://doi.org/10.1016/B978-0-12088772-9.X5022-5

Subekti, N., Duryadi, D., Nandika, D., Surjokusumo, S., \& Anwar, S. (2008). Distribution and Morphology Characteristic of Macrotermes gilvus Hagen in The Natural Habitat. Jurnal Ilmu Dan Teknologi Hasil 
Hutan, 1(1), 27-33.

Triplehorn, C. a., Johnson, N. F., \& Borror, D. J. (2005). Study Of Insects. In Borror and DeLong's introduction to the study of insects. Wenny, D. G., DeVault, T. L., Johnson, M. D., Kelly, D., Sekercioglu, C. H., Tomback, D. F., \& Whelan, C. J. (2011). Perspectives in ornithology the need to quantify ecosystem services provided by birds. Auk, 128(1), 114. https://doi.org/10.1525/auk.2011.10248

Wijaya, I. N., Adiartayasa, W., Sritamin, M., \& Yuliadhi, K. A. (2015). Dinamika Populasi Diaphorina citri Kuwayama (Homoptera: Psyllidae) dan Deteksi CVPD dengan Teknik PCR. Jurnal Entomologi Indonesia, 7(2), 78. https://doi.org/10.5994/jei.7.2.78 